\title{
EVALUATION OF SOME BAITS AND TRAPS AGAINST ORIENTAL WASP Vespa orientalis L. (HYMENOPTERA: VESPIDAE)
}

\author{
Saleh Mohammed Ali Bas and Batool Abdullah Karso \\ Dept. of Entomology, Plant Protection Collage of Agriculture Engineering Sciences, \\ University of Duhok, Kurdistan region-Iraq
}

(Received: February 24, 2020; Accepted for Publication: June 30, 2020)

\begin{abstract}
This study was carried out in the fields of Collage of Agricultural Engineering Sciences \University of Duhok. The efficiency of four types of traps and Baits were assessed to reduce the damage of the Oriental red wasp (Vespa orientalis L.) on honey bees and crops in the region.

Four different traps were used : wooden cage, small metal trap, Plastic white wide cylindrical trap, long cylindrical trap, as well as different baits in such trap as minced meat, Tuna fish, fesha ( sheep's lung ), chicken meal .

The results showed that the catch from the wooden cage was significantly higher than the rest of the traps with an average of 76 insect / trap. While metal trap was the lowest average of 26 insect / trap, fish bait was significantly highest with 67.75 insects / bait.
\end{abstract}

KEY WORDS: red wasp, traps, baits , mechanical control , Vespa orientalis .

\section{INTRODUCTION}

$\mathbf{R}_{\mathrm{sit}}^{\mathrm{ed}}$ wasp Vespa orientalis L. (Hymenoptera: Vespidae), is considered to be one of the most harmful pests to honey bee in many Arab countries [Khodairy, and Awad 2013 , and Abdelaal, and defrawy, 2014] , and its one of the strongest, biggest body in eusocial insects [Gatt, and Sciberras, 2014]. In Iraq, the oriental wasp is voracity a big pest to honey bee in apiary and an cultivate pest that effects and causes injury to orchards plants [Glaiim, 2009 and Al-Mahdawi, and Al-Kinani, 2011] . Sting of wasps cause ache and allergic response in allergic persons when it stings. [Sackmann, et al.. 2001].

The statics refer that because of hymenopteran stings, more than sixties death of persons in the United States since the past century (Akre, et al. 1980) also in Europe reported more than forty deaths for each year (Pollyea et al. 2009).

This pest also, clasp honey bee workers visiting blossoms and can go in to honey bee hives and bring off immature individual, honey, pollen and adults, and then fly back to their nests to feed their brood, consequently they cause damage to the hives and decreased productivity in honeybee products [Cranshaw, et. al 2011, Khodairy, and Awad, 2013, Abdelaal, and Eldefrawy, 2014, and Taha, 2014.]. In the beginning of spring apiarists in most countries fighting wasps by catching and killing individual workers, and queens, [Havron, and Margalith, 1995] and searching for nests near the hives place, to destroying nests by using fumigants pesticides as calcium cyanide . [Boeve, et al., 2014 , and Islam, et al., 2015]. In addition of using pinsecticidesusing poisonous baits or glue trap panels. While some of the bee-keepers prefer using obtainable materials in the apiary like sticky and color traps hanging on shrubs [Abdelaal, and El- defrawy, 2014].

In conclusion of the above attempts for protecting or reducing the serious damage of our orchard trees and honeybee hives from red wasps. the present work was undertaken to investigate the effect of different types of baits and traps for discover the best bait-trap group for catching social wasps, to reduce the harm of the social wasp fauna trapped and response to food sources supports the use of poison baits.

\section{MATERIAL AND METHODS}

Thise research was carried out in the orchards and apiary of College Agricultural Engineering Sciences, using four different types of traps and baits as following:

A- The traps Type:

1) Long Cylindrical trap: large size, diameter 22 $\mathrm{cm}$, height $50 \mathrm{~cm}$, It is made of transparent 
plastic, and it have two opening hole from two sides connect with funnel to entrance wasp. (fig1A)
2) Wooden trap: it is a cage form from wood and metals mesh sideways interlaced 30mesh $\backslash$ inch. cage was measuring $80 * 25 * 25 \mathrm{~cm}$. (fig 1B).
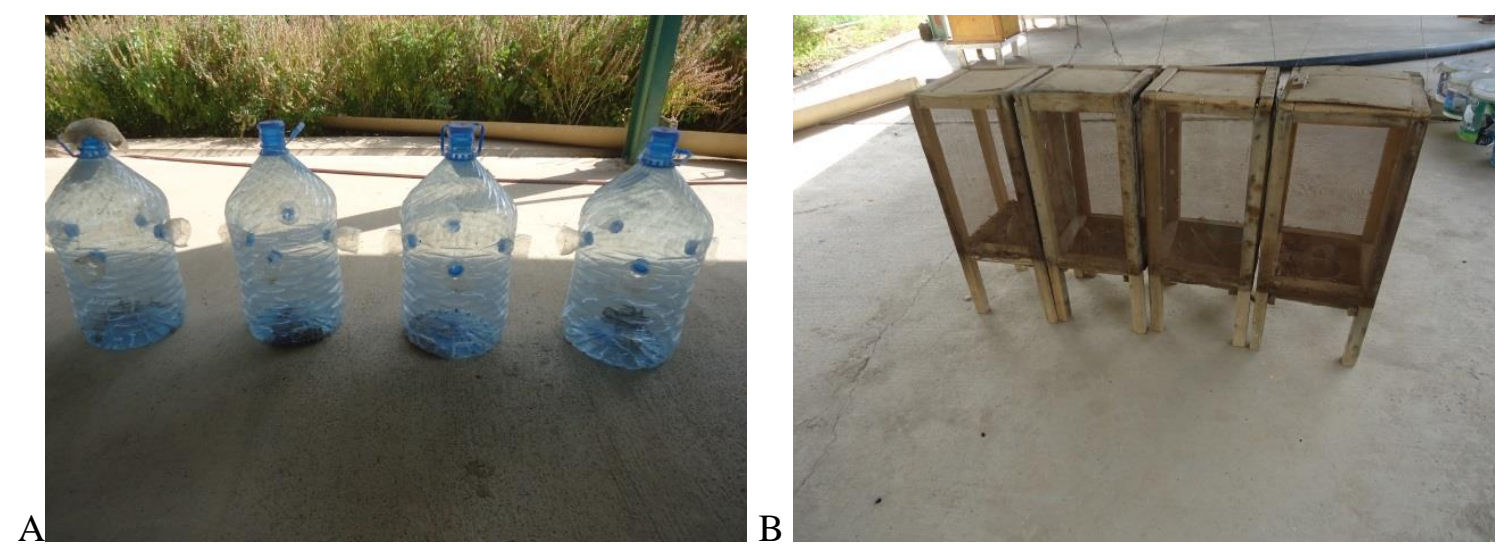

Fig. (1): A L Long Cylindrical trap. $\quad B \backslash$ Wooden trap

3) Metal (Tin) trap : It is metal cage (local tanak ), measuring with $40 \mathrm{~cm}$ high and $25 \mathrm{~cm}$. in width, it have tow opening hole from two sides connect with funnel to entrance wasp (fig 2A).

A

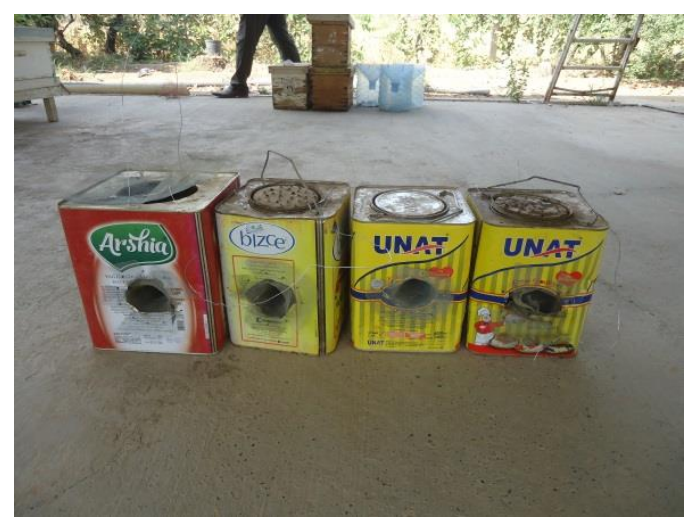

Fig. (2) : A Metal (Tin) trap.

\section{B- Baits type :}

Various types of baits were used: Minced meat, Tuna fish, Fesha (sheep's lung), chicken meal .

In this study we were spread the traps around the apiary and orchard fields, consisting of three replications for each type of traps and baits. Daily traps and wasps were enumeration, as well as change the different baits every 2 days for each trap, and data recorded began from the beginning of Jun - end of November 2019. The present study aimed to assess the efficiency of some types of local traps and the baits used and
4) White wide plastic cylindrical trap: Cylinder shape, diameter $30 \mathrm{~cm}$, height $30 \mathrm{~cm}$, It is made of thick white plastic, and has two opening hole from two sides connect with funnel to entrance wasp

(fig

2B).
B

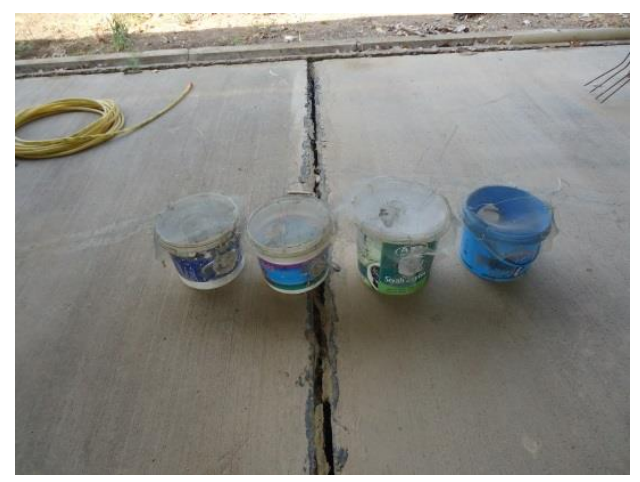

$\mathrm{B} \backslash$ White wide plastic cylindrical trap.

their effectiveness to controlling red wasp damage on the numerical density of this insect.

The results were analyzed statistically using (R.C.B.D.) and Duncans test to investigate the significant between means depending on (SAS).

\section{RESULTS AND DISSECTION}

The beginning of the appearance and disappearance of red wasp workers during the activity season (June - November ) 2019 .

The results showed that the Red wasp Vespa orientalis L. were found attacking vegetables , Orchards and honeybees Apis mellifera during 
June to November ( 2019). Data in table (1) showed that the $V$. orientalis started to appear in small numbers (1 wasps/week) during the first week of June and gradually increased to reached the highest number during the fourth week of August (252 wasps/week). A sharp decline observed during the first week of October. The number of wasps decreased gradually s until the fourth week of November. The monthly highest numbers of the hornets recorded in August (162.5 wasps/week) with an average temperature $\left(42.5^{\circ} \mathrm{C}\right)$ and relative humidity $(27.6 \%)$ followed by (30 wasps/week) in September with an average temperature $\left(41.6^{\circ} \mathrm{C}\right)$ and R.H. (27.7\%) and (24.5 wasps/week) in July with an temperature $\left(42.1^{\circ} \mathrm{C}\right)$ and R.H. $(27.1 \%)$.

The study results showed that the red wasp population started to come into view from the first week of June (1 hornets/week) and gradually increased in numbers and started declining at the end of October in the contrary to Gomaa and AbdEl-Wahab (2006) study, who mentioned that the numbers of wasps were increased from the second week of August (51 wasps/ trap) to the fourth week of September (3301 wasps/trap). Furthermore Taha (2014) reported that the highest number of captured oriental hornet was observed during October 2011 and November 2011 with average temperature and relative humidity $\left(24.4{ }^{\circ} \mathrm{C}\right.$, $69.5 \%$ and $17.3^{\circ} \mathrm{C}, 79.0 \%$ ), respectively. The obtained results confirmed the findings of Shoreit, 1998 who he stated that $V$. velutina, $V$. orientalis and $V$. tropica workers reached their peak in October and also Waghchoure-Camphor, 2013 where she observed that $V$. velutina seem to be the most serious predator of Apis mellifera at Islamabad which causes damage to honeybee colonies if not controlled. In our study the highest peak of hornet population was observed in August with average temperature and humidity $\left(42.1^{\circ} \mathrm{C}, 27.6 \%\right)$. These results agreed the observations of Shoreit 1998.

Table (1) : Population density of Red Wasps caught during the study season (2019).

\begin{tabular}{|c|c|c|c|c|c|c|c|}
\hline \multirow[t]{2}{*}{ Month } & \multirow{2}{*}{$\begin{array}{l}\text { No, of } \\
\text { Week }\end{array}$} & \multirow{2}{*}{$\begin{array}{l}\text { Mean of caught } \\
\text { wasp \week }\end{array}$} & \multirow{2}{*}{\begin{tabular}{l} 
Total \\
average \} $\\
{\text { month }}$ & \multicolumn{2}{|c|}{$\%$ Temperature } & \multicolumn{2}{|c|}{$\%$ Humidity } \\
\hline & & & & Week & month & Week & Month \\
\hline Jun. & First & 1 & \multirow[t]{4}{*}{2.75} & 36.1 & \multirow[t]{4}{*}{37.1} & 33.3 & \multirow[t]{4}{*}{31.6} \\
\hline Jun. & Second & 1 & & 38.7 & & 30.1 & \\
\hline Jun. & Third & 2 & & 32.25 & & 34.2 & \\
\hline Jun. & Fourth & 3 & & 41.7 & & 28.9 & \\
\hline Jul. & First & 5 & \multirow[t]{4}{*}{24.25} & 45.2 & \multirow[t]{4}{*}{42.1} & 23.3 & \multirow[t]{4}{*}{24.1} \\
\hline Jul. & Second & 7 & & 37.98 & & 22.3 & \\
\hline Jul. & Third & 28 & & 42.21 & & 25.2 & \\
\hline Jul. & Fourth & 46 & & 43 & & 25.5 & \\
\hline Aug. & First & 95 & \multirow[t]{4}{*}{162.5} & 42 & \multirow[t]{4}{*}{42.5} & 31.98 & \multirow[t]{4}{*}{27.6} \\
\hline Aug. & Second & 127 & & 42.8 & & 25.9 & \\
\hline Aug. & Third & 133 & & 43 & & 25.9 & \\
\hline Aug. & Fourth & 252 & & 42.45 & & 26.7 & \\
\hline Sept. & First & 42 & \multirow[t]{4}{*}{30} & 41.15 & \multirow[t]{4}{*}{41.6} & 25.4 & \multirow[t]{4}{*}{27.7} \\
\hline Sept. & Second & 33 & & 38.98 & & 30.0 & \\
\hline Sept. & Third & 25 & & 48.71 & & 28 & \\
\hline Sept. & Fourth & 20 & & 37.7 & & 27.46 & \\
\hline Octo. & First & 2 & \multirow[t]{4}{*}{1.5} & 35.9 & \multirow[t]{4}{*}{30.9} & 32.3 & \multirow[t]{4}{*}{44.5} \\
\hline Octo. & Second & 1 & & 33.2 & & 33.78 & \\
\hline Octo. & Third & 3 & & 30.9 & & 43.35 & \\
\hline Octo. & Fourth & 1 & & 23.7 & & 68.7 & \\
\hline Nov. & First & 2 & \multirow[t]{4}{*}{0.85} & 21.2 & \multirow[t]{4}{*}{19.5} & 61.5 & \multirow[t]{4}{*}{78.3} \\
\hline Nov. & Second & 1 & & 23.4 & & 77.5 & \\
\hline Nov. & Third & 0 & & 17.3 & & 87.1 & \\
\hline Nov. & Fourth & 0 & & 16.3 & & 87.3 & \\
\hline
\end{tabular}}
\end{tabular}




\section{Traps and Baits preference}

Traps:

The results of this experiment showed in table (2) that the best trap was wooden trap that given a significantly different in the caught, which gave a highest number from wasps worker in the field reached (76 wasp \trap), and followed by white wide cylindrical trap reached to 47.5 ( wasp $\backslash$ trap). The lowest number of red wasp was coughed by metal (Tin) trap reached to (26 wasp \trap ), The efficiency of metal trap was inferior as compared to the wooden trap and with plastic trap. The results confirmed the findings of scientists Bikos (1994) in Greece and by Shoreit (1998) in Egypt when used a similar type of trap with different kind of bait when used attract only wasps and not honeybees.

Table (2) : The efficiency of the trap type and the bait type in combating the red wasp

\begin{tabular}{|c|c|c|c|c|c|}
\hline Type of bait & Minced meat & chicken meal & Tuna fish & $\begin{array}{l}\text { Fesha } \\
\text { (sheep's } \\
\text { lung) }\end{array}$ & $\begin{array}{l}\text { Mean of trap } \\
\text { type }\end{array}$ \\
\hline \multicolumn{6}{|l|}{ Type of trap } \\
\hline Wooden trap & $79 d$ & $101 \mathrm{~b}$ & $122 \mathrm{a}$ & $45 f$ & $76 \mathrm{a}$ \\
\hline Metal (Tin) trap & $28 \mathrm{k}$ & $30 \mathrm{~g}$ & $42 \mathrm{~g}$ & $16 \mathrm{~m}$ & $26 \mathrm{~d}$ \\
\hline $\begin{array}{l}\text { White Wide } \\
\text { Cylindrical trap }\end{array}$ & $43 \mathrm{~g}$ & $55 \mathrm{e}$ & $72 c$ & $34 \mathrm{i}$ & $47.5 \mathrm{~b}$ \\
\hline $\begin{array}{l}\text { Long Cylindrical } \\
\text { trap }\end{array}$ & $43 \mathrm{~g}$ & $39 \mathrm{~h}$ & $66 \mathrm{e}$ & $24 I$ & $30.5 \mathrm{c}$ \\
\hline Mean of bait type & $39 c$ & $48 \mathrm{~b}$ & $67.25 \mathrm{a}$ & $26.75 \mathrm{~d}$ & \\
\hline
\end{tabular}

Baits:

The results showed major differences between baits statistically that gave the maximum total of red wasps were attracted to the traps which contain

tuna fish reached (67.25 worker), and followed by chicken meal bait, minced meat and fesha ( sheeps lung) means of the caught oriental wasp were 48,39 and 26.75 wasp $\backslash$ bait respectively. tuna fish became rancid as a results of heat summer season through test period due to the proses of oxidation and dehydration of tuna fish fats content to short series of aldehydes and ketones that make smell that caused to attracted red wasp to tuna fish baits

the results of the current experiment appeared that wooden trap with Tuna bait was most affected to controlling red wasp which catching more than another types of baits. This result approved with (Bacandritsos,2006), when test the Comparison between many types of catch wasp traps. The research showed that the red wasp prefer tuna fish baits and attracted and significantly differ from the other baits. (Table 2 ). The results match with previous research [Pereira, et.al., (2013).
The table (2) showed that wooden trap with tuna fish gave highest mean number of red wasp and followed by chicken meal bait and significantly differed as 122 and 101 wasp $\backslash$ trap respectively. Moreover the metal ( tin) trap using Fesha ( sheep's lungs ) bait was the lowest attractive bait tested was reached (16 wasp । trap).

The protein and fat content of the baits may have a major influence on its attractiveness to the wasps (Al Antary, et.al., 2016 ). In addition, This explanation agreed with the results reffered that bullmeat and sardinefish contain protein and fats reached $(22.21 \%, 21.75 \%)$, respectively. Besides, sardinefish contain more fat content than bullmeat $(3.46 \% .2 .32 \%)$. because of the sardinefish is more wet than bullmeat, the fish meat released the smell slowly with long time than the other baits. However, sardine meat in the glass trap within experiment period (24 hours) had become rancid through test period because of the proses of oxidation and dehydration of tuna fish fats content to short series of aldehydes and ketones that make smell that caused to attracted red wasp to tuna fish baits [Triqui, and Bouchriti,( 2003) ; Gomes, et.al., (2013)], that explained why the red wasp attracted to wooden trap with tuna fish baits more than the others. 


\section{REFRENCES}

Abdelaal, A.A.A. and B.M. El- defrawy, 2014. Efficacy of new designed traps for controlling the oriental hornet (Vespa orientalis) in Egyptian apiaries and its measurements. International Journal of Advanced Research, 2(10): 1-8.

AKRE R. D., Green A., Macdonald J. F., Landolt P. J., Davis H. G., 1980.- Yellowjackets of America North of Mexico.- Agriculture Handbook 552, U.S. Department of Agriculture, Washington, USA.

Al Antary, T.M., B.N. Al- Heyari and I.K. Nazer, 2016. Acceptance of the oriental wasp Vespa orientalis L. (Hymenoptera: Vespidae) to different baits. Advances in Environmental Biology, 10(12).

Al-Mahdawi, Q.H.A. and M.A. Al-Kinani, 2011. Economical damage of the red wasp Vespa orientalis and yellow wasp Polistes olivaceus on grapes. Diyala Agricultural Sciences Journal, 3(2): 216-222.

Bacandritsos, N., L. Papanastasiou, C. Saitanis and E. Roinioti, 2006. Three non-toxic insect traps useful in trapping wasps enemies of honey bees. Bulletin of Insectology, 59(2): 135-145.

Bassam N. Al Heyari et al, 2016 Advances in Environmental Biology, 10(12) December 2016, Pages: 1-8 .

Bikos, A. 1994. Experience and Inventions. Apicultural review, 2: 62-65.

Boeve, J., K. Honraet and B. Rossel, 2014. Screening of repellents vespid wasps. Insects, 5: 272286.

Cranshaw W. S., LARSEN JR. H. J., ZIMMERMAN R. J., 2011.- Notes on fruit damage by the European paper wasp, Polistes dominula (Christ) (Hymenoptera: Vespidae).Southwestern Entomologist, 36 (1): 103-105.

Gatt, A. and A. Sciberras, 2014. The Oriental Hornet. http://www.timesofmalta.com/articles/ view/20140824/environment/The-OrientalHornet.533029 8 .

Glaiim, M.K., 2009. Hunting behavior of the oriental hornet Vespa orientalisL ., and different behavior of the honey bee, Apis millefira L., in Iraq.Bull. Iraq Nat. Hist. Mus, 10(4): 17-30.

Gomes, M.C., S. Silva, M.A. Faustino, M.G. Neves, A. Almeida, J.A. Cavaleiro, J.P. Tome and A. Cunha, 2013. Cationic galactoporphyrin photosensitisers against UV-B resistant bacteria: oxidation of lipids and proteins. Photochemical and Photobiological Sciences, 12(2): 262-271.
Gomma, A.M. and T.E. Abd El-Wahab 2006. Seasonal abundance and the efficiency of yeast liquid culture (Candida tropicalis) as pait for apturing the oriental wasps (Vespa orientalies Fab.) under Egyptian Environment. J. Appl. Sci. Res., 2(11): 1042-1046.

Havron, A. and Y. Margalith, 1995. Parasitizatio of Vespa orientalis $L$. nests by Sphecophaga vesparum Curtis (Hymenoptera: Vespidae, lchneumonidae). Phytoparasitica, 23(1): 1925.

Islam, N., F. Iftikhar and R. Mahmood, 2015. Seasonal variation in hornets spp. and efficiency of different traps as a tool for control. American Journal of Agricultural Science, 2(6): 223-230.

Khodairy, M.M. and A.A. Awad, 2013. A study on the sensory structure, in relation to some behavioral ecology of the oriental hornet (Vespa orientalis L.) (Hymenoptera: Vespidae). Life Science Journal, 10(2): 12071215.

Pereira, A.J., M. Masciocchi, O. Bruzzone and J.C. Corley, 2013. Field preferences of the social wasp Vespula germanica (Hymenoptera: Vespidae) for protein-rich baits. Journal of Insect Behavior, 26(5): 730-739.

Pollyea D. A., George T. I., Corless C., Gotlib J., 2009.- When yellow jackets attack: recurrent and severe anaphylactic reactions to insect bites and stings.- American Journal of Hematology, 84: 843-846.

Sackmann, P., M. Rabinovich and J. Corley, 2001. Successful removal of German yellow jackets (Hymenoptera: Vespidae) by toxic baiting. Journal of Economic Entomology, 94(4): 811816.

Shoreit, M. N. 1998. Field observations on the seasonal abundance and control of the oriental hornet, Vespa orientalis L. attacking honeybee colonies in Egypt. J. of App. Sci. 13 (4): 250256.

Taha, A.A., 2014. Effect of some climatic factors on the seasonal activity of oriental wasp, Vespa orientali $L$. attacking honey bee colonies in Dakahlia Governorate, Egypt. Egyptian Journal of Agricultural Research,92(1): 43-51.

Triqui, R. and N. Bouchriti, 2003. Freshness assessments of moroccan sardine (sardine pilchardus): comparison of overall sensory change to instrumentally determined volatiles. Journal Agricultural Food Chemistry, 51: 7540-7546. 


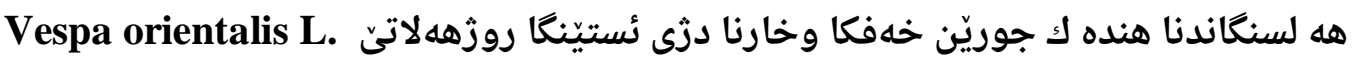
(Hymenoptera: Vespidae)

يوخته

ئه فه فهولينه ياهاتيه ئهنجام دان هه ر ز هه يفا حزيرانيّ ههتا دوماهيا جريا دووى ل سالا 2019. زكيلِكه هيّن كوليزا زانستيّن ئهندازياريا جاندني/ زانكويا دهوك- هه ريّما كوردستانا عيراقي. ئه ثه كولينه

خو قهت كَيت جار جوريّن خه فكا وجار جوريّن خارنى هاتينه ههلسنعَاندن بو كيّمكرنا زيانيّن ئستيّنگًا

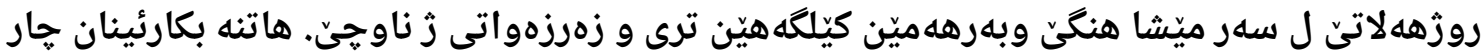

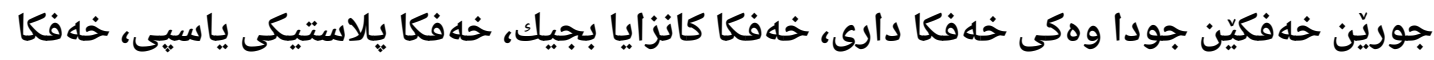
يالاستيكى يادريّز وجار جوريّن خارنيّن جودا ل ناق خه فكادا وهكى گوشتى يهزى

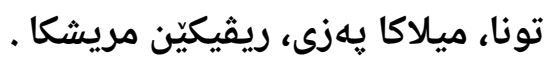

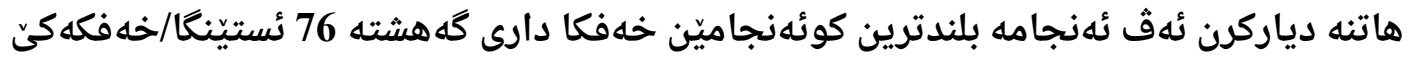

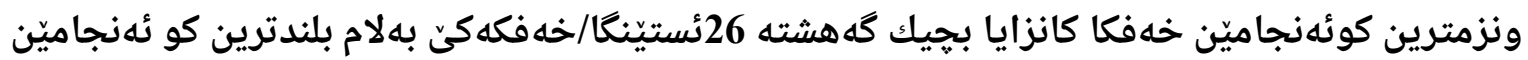

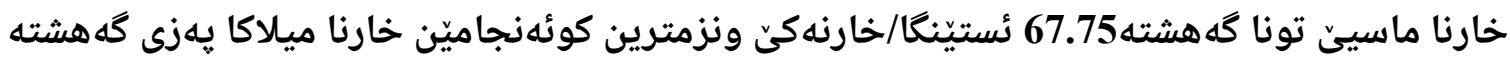
26.75

تقييم بعض الطعوم والمصائد ضد الزنبور الاحمر (Vespa orientalis L. : Vespidae : Hymenoptera)

الخلاصة نفذ هذا البحث في حقول كلية العلوم الهندسة الزراعية \جامعة دهوك , حيث تم دراسة كفاءة أربعة أنواع من المصائد والطعوم في الحد من أضرار حشرة الزنبور الشرقي الأحمر (Vespa orientalis L. النحل والمحاصيل في المنطقة.

تم استخدام عدة مصائد وهي :قفص مشبك خشبي , مصيدة المعدنية الصغيرة (تنك ) ،مصيدة اسطوانية بيضاء ، مصيدة الاسطوانية شفافة . كما تم دراسة كفاءة طعوم مختلفة في هذه المصائد مثل اللحم المفروم , السمك، رئة الأغنام (فشة)، أحشاء دواجة الاسطن.

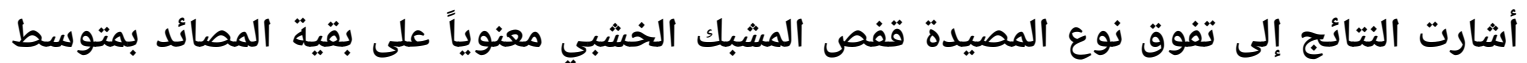
صيد 76 حشرة /مصيدة وأعطت المصيدة المعدنية أقل متوسط 26 حشرة /مصيدة، وتفوق طعم السمك لمك بفرق معنوي كبير حيث كان متوسط الصيد 67.25 حشرة / طعم وكان أقل طعم فاعلية رئة اغنام ( فشة ) بمتوسط صيد 26.75 حشرة / طعم.

الكلمات الدالة : الزنبور الاحمر , مصائد , طعوم , مكافحة ميكانيكية . 